\title{
A Land Cover Changes Model Based on Carbon Stock in the Mount Patah Region of, Bengkulu-Indonesia
}

\author{
Widya Prarikeslan, Dedi Hermon, Eri Barlian, Indang Dewata, Iswandi Umar
}

\begin{abstract}
Forest cover in Bengkulu is reduced. Data from WARSI shows, 1990 forest cover areas in the province are approximately 1,009,209 hectares or $50.4 \%$ of the land area reaching 1,979,515 hectares. But now, it is only 685,762 hectares of the area of his blood. That is, the period of 25 years, there is a forest cover decline of 323,447 hectares. Forest and land cover changes are the largest contributor to greenhouse gas emissions. The purpose of this article is to see land cover changes based on carbon stock in the years 2009 and 2018. Model of land cover change based on carbon stock year 2028 and 2038. The method of this research uses the calculation of the Stock Difference Approach with spatial analysis of national land closure of Landsat imagery 2009-2018 and biomass data for forest inventory results Geographic Information System (GIS). The results of this research were the reduced forest area and the change in land use changed from 2009 and 2018. So carbon stock is also increasingly reduced.
\end{abstract}

Keywords: GIS, land use, carbon, patah mount, Bengkulu.

\section{INTRODUCTION}

L mainly for the development of housing, offices, industry, and trade. Conditions that cause environmental degradation, Southern region the watershed should consider the environmental aspects in the development process [1,2]. Therefore, landscape planning to explore the potential of watershed resources and management of landscape is required by considering environmental impacts to support low-carbon community programs (LCS). Rapid development has caused the change of land cover, where land awakened increasingly dominate and urged natural land (forest) to change function $[3,4]$. The problem of fullness is important in the world, especially in developing countries including

Revised Manuscript Received on May 15, 2020.

* Correspondence Author

Widya Prarikeslan*, Department of geography and doctoral program of environmental science, Universitas Negeri Padang, Padang, Indonesia. Email: widya_geo@fis.unp.ac.id

Dedi Hermon, Department of geography and doctoral program of environmental science, Universitas Negeri Padang, Padang, Indonesia. Email: dihermon006@gmail.com

Eri Barlian, Department of doctoral program of environmental science, Universitas Negeri Padang, Padang, Indonesia. Email: eribarlian@unp.ac.id

Indang Dewata, Department of doctoral program of environmental science, Universitas Negeri Padang, Padang, Indonesia. Email: indangdewata@fmipa.unp.ac.id

Iswandi Umar, Department of geography and doctoral program of environmental science, Universitas Negeri Padang, Padang, Indonesia. Email: iswandi_u@yahoo.com

(c) The Authors. Published by Blue Eyes Intelligence Engineering and Sciences Publication (BEIESP). This is an open access article under the CC BY-NC-ND license (http://creativecommons.org/licenses/by-nc-nd/4.0/)
Indonesia, one of the population problems is the rapid growth of residents who need proper living and decent life [5,11].

The Anthropogenic activity of converting local land cover into an urban area that is very difficult to be changed back into the Carbon stock area as originally [6-8].

Bengkulu is one of the provinces in Indonesia that is located on the island of Sumatra with a population of about 1.9 million inhabitants. The area is approximately 2 million hectares, of which 0.9 million hectares of forests and 0.008 million hectares are peatlands.

The focus to improve Bengkulu environment: (a) The diminishing forest cover of Bengkulu should be wary. This is related to potential disasters that occur, e.g. floods and landslides; (b) Indonesia WARSI Conservation Community Data shows, in 1990 forest cover area in Bengkulu around $1,009,209$ hectares. Now shows only 685,762 hectares; (c) The reduction factor of forest cover is to start overland function, used as oil palm plantation or industrial plant, until mining; and (d) Plan for provincial spatial space (RTRW) Bengkulu that serves as the coordinator of the regional government's important sectoral program implemented. RTRW closely relates to the arrangement of forests that are certainly not for the region for various interests.

Forest cover in Bengkulu is reduced. The Indonesian WARSI conservation community Data shows, on 1990 forest cover areas in the province, about 1,009,209 hectares or 50.4 $\%$ of the land area reaching 1,979,515 hectares. But now, it is only 685,762 hectares of the area of his blood. " That is, the period of 25 years, there is a forest cover decline of 323,447 hectares. This is the same as losing 36 hectares per day, even 1.5 hectares per hour, "said Indonesian conservation community director Warsi, Rudi Syaf, at the national Seminar on legal dimension and protection of environmental management at the University of Bengkulu (UNIB), early October 2019.

Emission factors are formed from the value of carbon deposits in various types of land cover. Carbon backup information on different types of forest enting to calculate status and emission levels. Forest carbon stock has varying values. These variations are influenced by several factors, such as vegetation type, forest type, soil type, climate type and rainfall, topography, altitude, and other biophysical conditions, including silviculture and forest management techniques applied. Countries with more prosperous economic activity may need more energy and more carbon emissions, which further leads to higher carbon prices [9].

Published By:

Blue Eyes Intelligence Engineering \& Sciences Publication

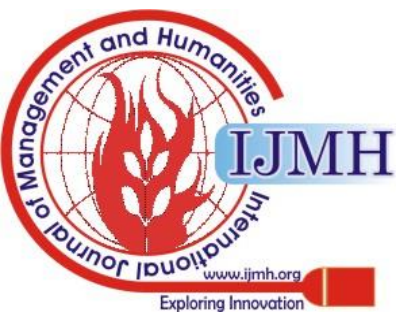


Climate change and anthropogenic disorders can severely damage the service of the absorption ecosystem and carbon storage [10]. Comprehensive carbon backup information in various forest types and land use is still limited. Carbon stock information and emission factors are required for various entities, both central and government institutions, non-governmental institutions and other institutions as climate change mitigation practitioners. One of the ways to control climate change is to reduce greenhouse gas emissions $(\mathrm{CO}, \mathrm{CH}, \mathrm{N} \mathrm{O})$, i.e, to maintain natural forest integrity and increase the population density of trees outside the forest. Plants absorb the acid gas charcoal (CO) from the air through the process of photosynthesis, subsequently converted into carbohydrates, then spread throughout the body of the plant and eventually piled in the body of the plant. The carbon filling process $(\mathrm{C})$ on the body of the living plant is called the sequencing process ( $\mathrm{C}$ sequestration). Measuring the amount of carbon stored in the body of a living plant (Biomasa) on land can depict the number of CO-plants in the atmosphere. Measurement of carbon stock that are still stored on the part of the Dead plant (Necromasa) indirectly describes the CO is not released into the air through combustion. The purpose of this research is land-use change based on carbon stock and models of land-use change based on carbon stock.

\section{RESULT METHODS}

\section{A. Research Location}

The research was conducted in the Patah mount region of Bengkulu. The primary data collection was done on 14-18 March 2020 and the data processing in the laboratory.

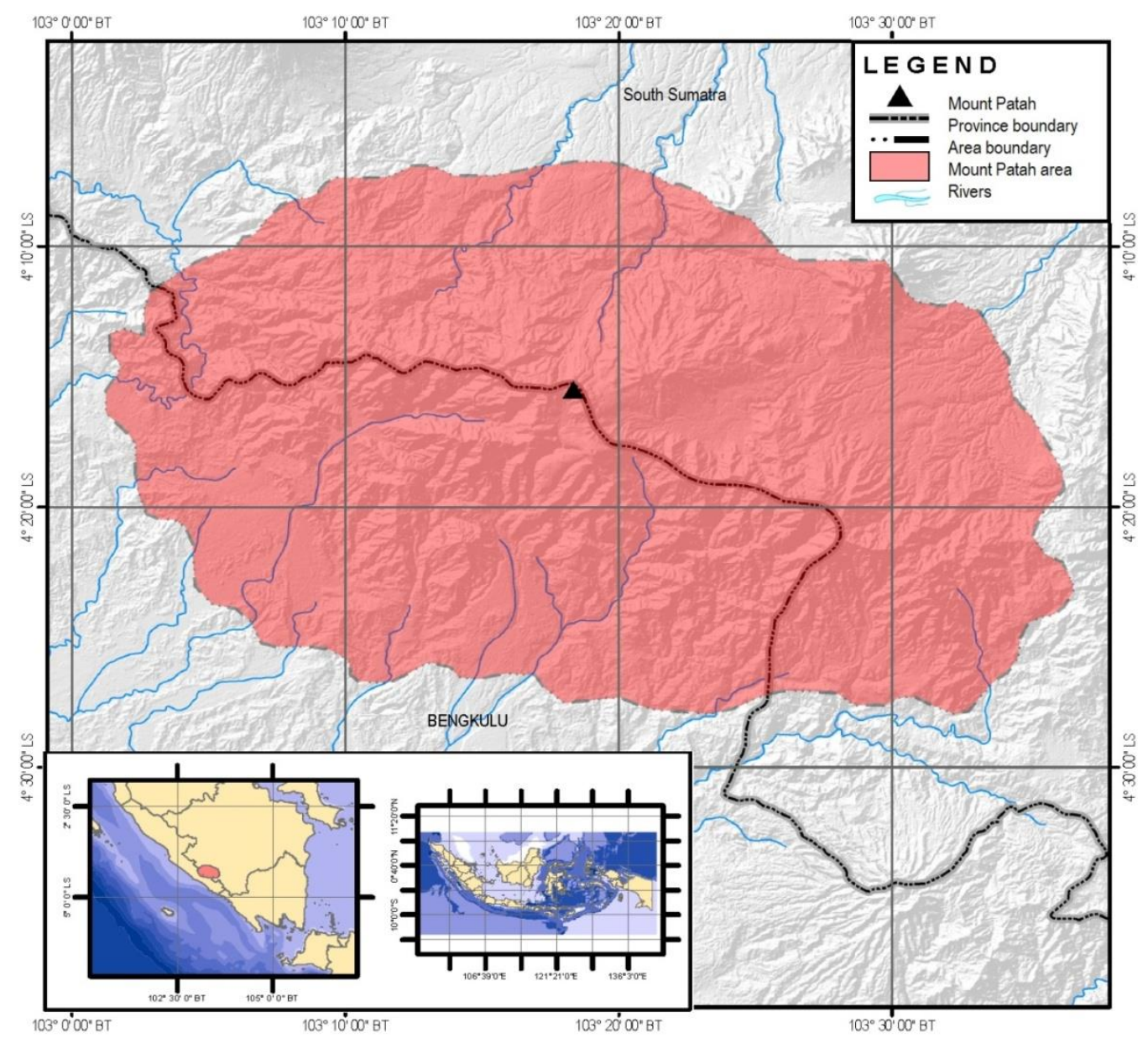

Fig. 1. Research Location Map

Patah mount region is a quaternary-age volcano, a very dense tropical rainforest vegetation, located in the west of Mount Dempo in South Sumatra, Indonesia.

\section{B. Data and Samples}

\section{Change of land cover}

The tools used in research use the digital map analysis approach. Digital map Analysis by using a GIS that is done by an overlapping map of land use result of image interpretation year 2009 and 2018 to get land change. Interpretation of Landsat land use on the screen for land use and then perform field checking to prove the result of interpretation image. The processing of image data is done through several stages. The first stage is a composite image and geometry correction; That includes the preparation of data retrieval control points between Earth map images, control point determination is done by the Universal Mercator Transverse (UTM) system. The second stage is then cropping. The third stage is image enhancement and a combination of channel selection. Software used is Arc-GIS.

Blue Eyes Intelligence Engineering \& Sciences Publication

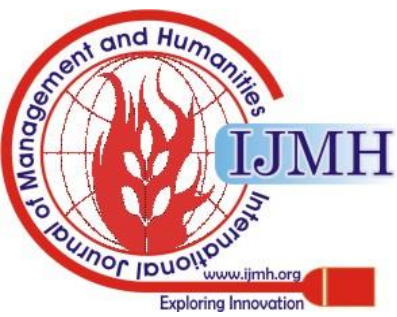




\section{Calculation of carbon stock}

The calculation of carbon stock is conducted through analysis using the activity data and carbon backup data/emission factors/absorption factors for each type of land cover. Activity data is data about the quantitative magnitudes of human activities or activities that can remove and/or absorb greenhouse gases over a certain period. The activity data used in this research is land cover data for the year 2009 and 2018. The emission factors/absorption factors in this research use a carbon stock on the surface of 9 land cover classes obtained from the results of National Forest Inventory (IHN) data and various literature on a national scale [12].

The calculation of carbon stock is carried out by calculating the area of each of the land cover of the Patah mount region in 2009 and 2018 which is called the annual activity data. The area of each type of land cover multiplied by the carbon stock number, then calculated the total carbon stock each year, can be seen in the equation.

$$
X=D A T \xi X K \Pi L
$$

Description:

$\mathrm{C}=$ Total carbon stock of year

DAT = Annual Activity Data

CKPL $=$ Carbon stock of Land Cover

\section{Carbon Stock Prediction}

The prediction of carbon stock is the approximate carbon that will occur during the next 10-20 years. The carbon projection uses the calculation of the engineering formula used by judges [11]. Where previously the judge used this formula to predict changes in land cover that would occur several years ahead. The land cover will directly affect the amount of carbon occurring, can be seen in Equation 2. Based on the total carbon obtained in 2009-2018 can be done the approximate phase of carbon stock for the year 2028 and 2038. Estimates of changes in carbon stock are projected to be 10 -20 years ahead because the cover data used has a period of 10 years. Analysis of estimated carbon stocks can be seen in the following equation.

$$
\begin{gathered}
\Pi X K=X K(\tau 1-\tau 2) / X K \tau 1 \\
X K \Pi=X K \tau 2-(\Pi X K \xi X K \tau 2)
\end{gathered}
$$

Description:

PCK = Proportion of total carbon stock (2009-2018)

CK (t1-t2) = Total carbon stock difference (2009-2018)

CK t1 = Total carbon stock year 2009

$\mathrm{CKP}=$ Projected total carbon stock

CK t2 = Total carbon stock year 2018

\section{ANALYSIS RESULTS}

In table 1 looks the most reduction in the scrub and the most numerous additions are open ground. Based on the results of the research, the percentage of land cover change was obtained in 2009 with 2018 shown in Fig. 2.

Table- I: Land use Area in 2009, 2018 and its Changes

\begin{tabular}{lllll}
\hline \multirow{2}{*}{ No } & \multirow{2}{*}{ Land Cover } & \multicolumn{3}{c}{ Area (Ha) } \\
& & $\mathbf{2 0 0 9}$ & \multicolumn{1}{c}{$\mathbf{2 0 1 8}$} & \multicolumn{1}{c}{ Changes } \\
\hline 1 & Primary Forest & 93417.84 & 93166.52 & -251.32 \\
2 & Secondary forest & 35829.55 & 33644.10 & -2185.45 \\
3 & Settlements & 13.11 & 21.66 & 8.55 \\
4 & Mining & 0.00 & 37.58 & 37.58 \\
5 & Dry-Land farming & 51266.75 & 56675.45 & 5408.70 \\
6 & Swamp & 25.71 & 24.71 & -1.00 \\
7 & Rice fields & 2278.82 & 2373.94 & 95.12 \\
8 & Shrub & 10657.02 & 6951.56 & -3705.46 \\
9 & Open ground & 77.47 & 670.74 & 593.26 \\
\hline
\end{tabular}

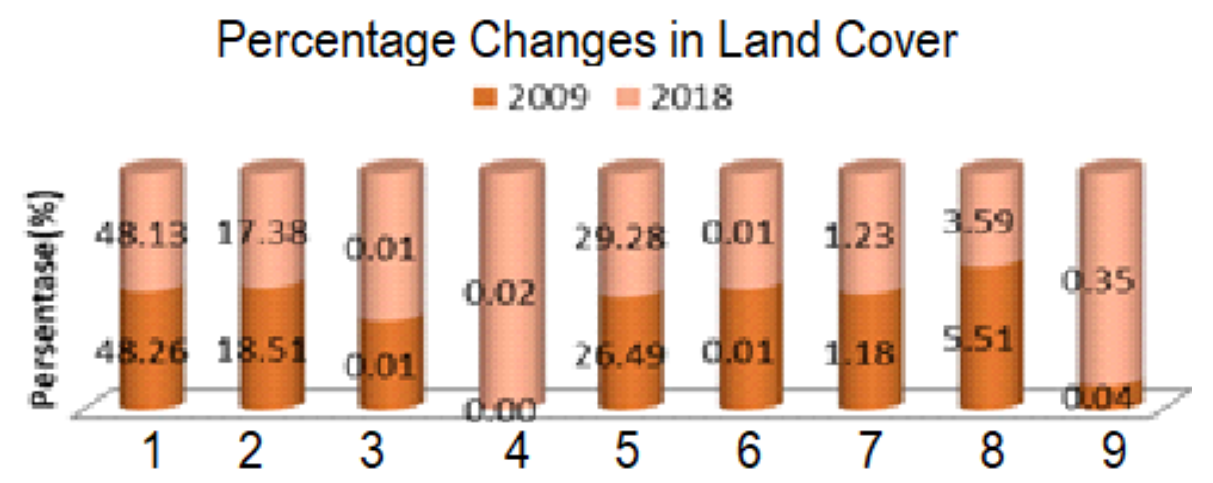

Fig. 2. Percentage Changes in Land Cover 2009 and 2018

Data on quantitative magnitudes of human activity in the Patah mount region that can remove and/or absorb greenhouse gases in a certain period. The activity data used in this research is a land cover change data for the years 2009 and 2018.

Land use in Patah mount region is spatially presented on a land-use map Fig. 3. The result of land use interpretation in the Patah mount region from Landsat classifies land use into nine types of land use i.e forest, primary forest, secondary forest, settlement, mining, dryland farming, swamps, paddy fields Scrubs and open ground. Primary forests, secondary forests, dry-field farms, and declining bushland are caused by deforestation and forest degradation. In contrast to non-forest land covers such as rice fields, shrubs, and open ground there is widespread addition. In the year 2009, there is no mining but in 2018 there is a mining area that could have an impact on environmental damage.

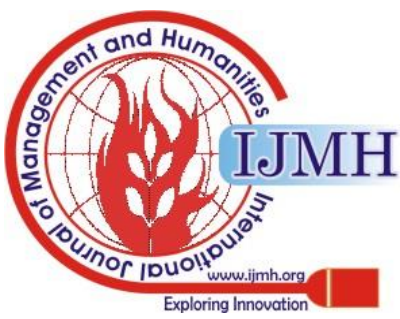




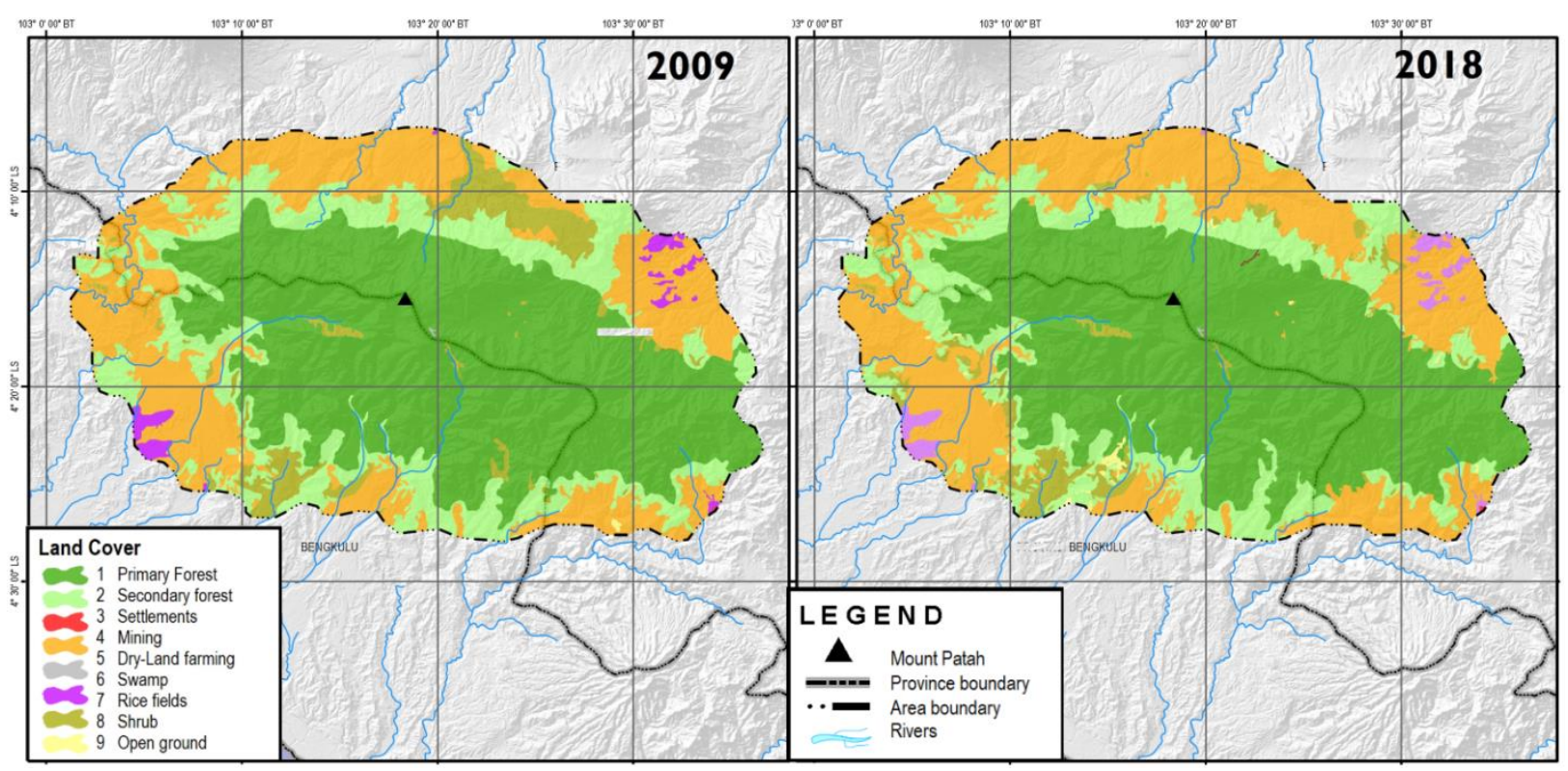

Fig.3. Map of changes in land cover of the Patah mount region in 2009-2018

The The dynamics of land cover in Patah mount region will affect the dynamics of carbon stock on the earth surface. The carbon stock calculated in this research is in 4 periods from the years 2009, 2018, 2028 and 2040. Graph of carbon deposits (Fig 4) shows the change in the national scale of carbon stock from 2009 until 2040. According to the chart, the total carbon stock tends to decline from 16802213.12 Ton/ha in 2009 to 15904294.36 Ton/ha in 2040. The decline in carbon stock is closely related to 2009-2040 land cover changes..

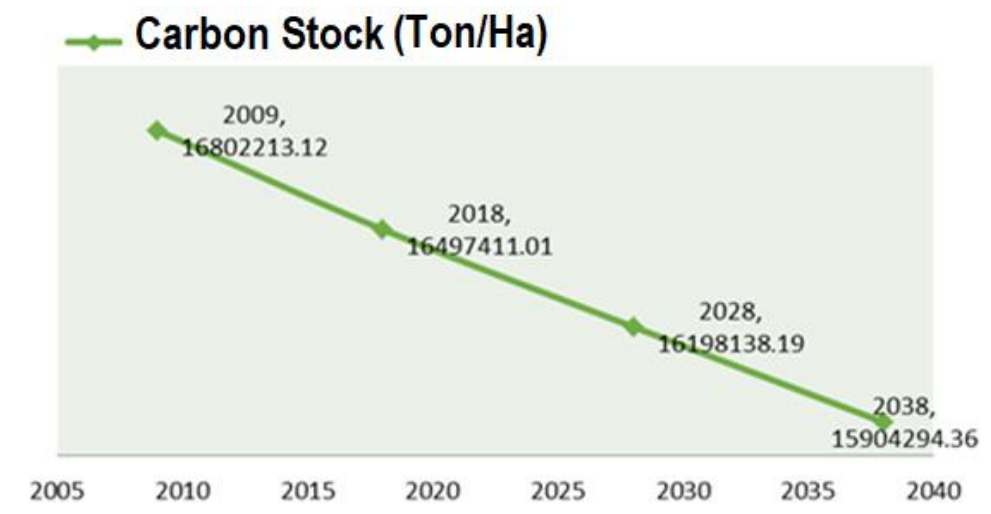

Fig. 4. Carbon Stock Values (Ton/Ha) in the Patah Mount Region

\section{CONCLUSION}

The land use in the Patah mount region of Bengkulu is grouped into nine types of land use with the largest area to the smallest in the years 2009 and 2018 consist of primary forest, secondary forest, dry-land agriculture and declining shrub. For non-forest land, the cover is experiencing widespread additions. While the results of the calculation of carbon stocks in the research showed that total carbon reserves tended to decrease from 16802213.12 Tons/ha in 2009 to 15904294.36 Tons/ha in 2040.

\section{ACKNOWLEDGEMENT}

This research was supported by Universitas Negeri Padang (UNP). We also thank of Chairman of Postgraduate UNP and Staff, and Students involved in research for their support in this research.

\section{REFERENCES}

1. X. Zhang, C. Wenhong, G. Qingchao and W. Sihong, Effects of land-use change on surface runoff and sediment yield at different watershed scales on the Loess Plateau. International Journal of Sediment Research, Vol.25, Issue. 3, pp.283-293, 2010

2. I. Umar, I. Dewata, E. Barlian, D.Hermon and Y. Suasti, Priority Selection of Residential Development Areas with Flood Hazard in Limapuluh Kota District, West Sumatra. International Journal of GEOMATE, Vol. 15, Issue. 52, pp. 152-158, 2018

3. W. Prarikeslan, D. Hermon, Y. Suasti and A.Putra, Density, coverage and biomass of seagrass ecosystem in the Lobam Island, Bintan Regency-Indonesia. In IOP Conference Series: Earth and Environmental Science, Vol. 314, No. 1, pp. 012024, 2019

4. E. Berlian, D.Hermon and I. Umar, Kajian Dinamika Penduduk dan Dampaknya Terhadap Lingkungan di Kota Padang, 2011.

5. Z. Qiu, Z. Feng, Y. Song, M. Li and P. Zhang, Carbon sequestration potential of forest vegetation in China from 2003 to 2050: Predicting forest vegetation growth based on climate and the environment. Journal of Cleaner Production, Vol. 252, pp.119715. 2020

6. C. Yu, J. Feng, K. Liu, G. Wang, Y. Zhu, H. Chen and D. Guan, Changes of ecosystem carbon stock following the plantation of exotic mangrove Sonneratia apetala in Qi'ao Island, China. Science of The Total Environment, Vol. 717, pp.137142. 2020

Published By:

Blue Eyes Intelligence Engineering \& Sciences Publication

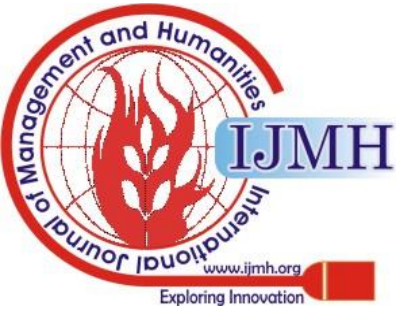


7. F. Wen, N. Wu and X. Gong, China's carbon emissions trading and stock returns. Energy Economics, Vol. 86, pp.104627. 2020

8. M.A. Kusumaningtyas, A.A. Hutahaean, H.W. Fischer, M. Pérez-Mayo, D. Ransby and T.C Jennerjahn, Variability in the organic carbon stocks, sources, and accumulation rates of Indonesian mangrove ecosystems. Estuarine, Coastal and Shelf Science, Vol.218, pp.310-323, 2019

9. T.J. Kakisina, S. Anggoro and A. Hartoko, (2015). Analysis of the Impact of Land Use on the Degradation of Coastal Areas at Ambon Bay-mollucas Province Indonesia. Procedia Environmental Sciences, Vol, 23, pp.266-273. 2015

10. A. Tosiani, Analisis Multi-Temporal Citra Satelit Landsat Untuk Pemantauan Cadangan Karbon Nasional. Seminar Nasional Geomatika 2017: Inovasi Teknologi Penyediaan Informasi Geospatial Untuk Pembangunan Berkelanjutan. 2017

11. T.A.Tanto, A. Putra, D. Hermon and H. Damanhuri, Suitability of Seagrass Ecosystem for Marine Ecotourism in Padang City, West Sumatera Province. Forum Geografi. Vol. 32, Issue. 1, pp. 88-95, 2018.

12. D. Hermon, Mitigation and Adaptation: Disaster of Climate Change. Sara Book Publication. India, 2019

\section{AUTHORS PROFILE}

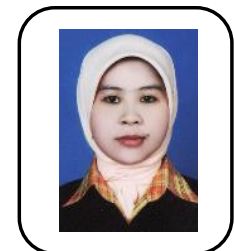

Widya Prarikeslan, is a Research and Lecturer of Geography and Environmental Sciences, Universitas Negeri Padang, obtained the Master Degree in Oceanography at Bandung Institute of Technology. He is actively involved in any researches regarded to oseanography, aquatic environment and produces several scientific works in the form of Scopus indexed journals (ID: 57209394362). He was the chair of the Study Program of Geography, Universitas Negeri Padang as well as a student Doctoral Program of Environmental Science, Universitas Negeri Padang.

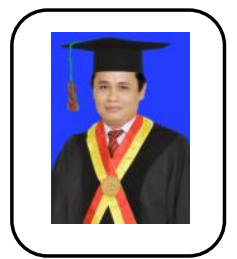

Dedi Hermon, is a Professor of Disaster Geography, obtained the Doctorate Degree in Doctor Program Natural Resources Management and Environment at Bogor Agriculture University, 2009. He is actively involved in any researches regarded to natural disaster, land cover, carbon stock and produces several scientific works in the form of Scopus indexed journals (ID: 57200409691) and scientific books both national and international publications. He was the chair of the Study Program of Geography, Universitas Negeri Padang as well as a student Doctoral Program of Environmental Science, Universitas Negeri Padang.

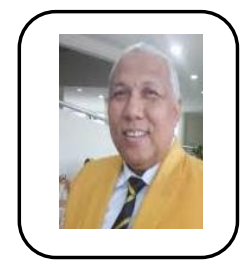

Eri Barlian, is a Professor of Environmental Education, obtained the Doctorate Degree in Doctor Program Education Science at Universitas Negeri Jakarta, 1999. He is actively involved in any researches regarded to environmental education, sports, recreation and disaster and produces several scientific works in the form of Scopus indexed journals (ID: 57202293479). He is Chair of Doctoral Program of Environmental Science, Universitas Negeri Padang.

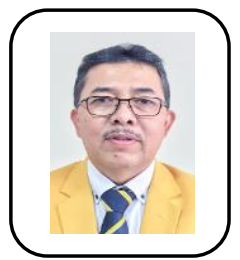

Indang Dewata, is an Associate professor of Environmental Science, obtained the Doctorate Degree in Doctor Program Education Science at Universitas Indonesia, 2009. He is actively involved in any researches regarded to environmental science, chemical and produces several scientific works in the form of Scopus indexed journals (ID: 57202287960). $\mathrm{He}$ is Chair of Masters Program of Environmental Science, Universitas Negeri Padang.

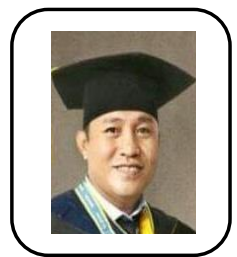

Iswandi Umar, is an Associate professor of Environmental Science, obtained the Doctorate Degree in Doctor Program Natural Resources Management and Environment at Bogor Agriculture University, 2015. He is actively involved in any researches regarded to environmental science, geography and produces several scientific works in the form of Scopus indexed journals (ID: 57204825796). He is Chair of Masters Program of Geography Education, Universitas Negeri Padang.

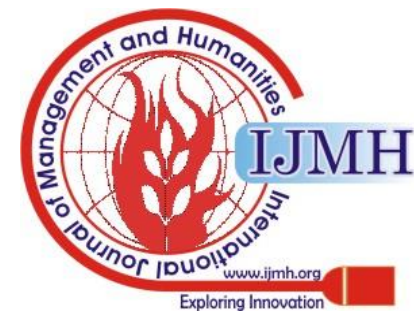

